\title{
The effect of selenium supplementation before calving on early-lactation udder health in pastured dairy heifers
}

\author{
A. Ceballos-Marquez, ${ }^{\star} \dagger^{1}$ H. W. Barkema, $¥ \S$ H. Stryhn, $\dagger$ J. J. Wichtel, $\dagger$ J. Neumann,\# A. Mella, $\|$ J. Kruze, $\|$ \\ M. S. Espindola,T and F. Wittwer\# \\ *Departamento de Sistemas de Producción, Universidad de Caldas, Manizales, Colombia \\ †Department of Health Management, Atlantic Veterinary College, University of Prince Edward Island, Charlottetown, PEI, Canada C1A 4P3 \\ fDepartment of Production Animal Health, Faculty of Veterinary Medicine, University of Calgary, Calgary, AB Canada T2N 4N1 \\ $\S$ Department of Reproduction, Obstetrics and Herd Health, Faculty of Veterinary Medicine, Ghent University, Merelbeke, Belgium \\ \#Department of Veterinary Clinical Sciences, Faculty of Veterinary Sciences, and \\ ||Microbiology Department, Faculty of Sciences, Universidad Austral de Chile, Valdivia, Chile \\ TCooperativa Agrícola y Lechera de La Unión Ltd., La Union, Chile
}

\section{ABSTRACT}

Selenium (Se) deficiency has been associated with lowered resistance to mastitis in dairy cattle. However, little published data exists on the effect of Se supplementation before calving on udder health of pastured dairy heifers. Further, the relative efficacy of injectable barium selenate and oral organic Se for improving udder health in cows has not previously been tested. The objectives of this study were to determine the effects of precalving Se supplementation and type of supplementation on the blood activity of glutathione peroxidase and measures of udder health immediately after calving and during the first month of lactation in pastured dairy heifers. One hundred forty pregnant Chilean Holstein-Friesian heifers were fed a basal diet containing, on average, 0.15 $\mathrm{mg}$ of $\mathrm{Se} / \mathrm{kg}$ of dry matter. One month before predicted calving, heifers were allocated to 1 of 3 groups. Group $1(\mathrm{n}=49)$ received no supplementary Se, group 2 (n $=46)$ received a single subcutaneous injection of Se (1 $\mathrm{mg} / \mathrm{kg}$ of live weight, as barium selenate), and group $3(\mathrm{n}=45)$ was fed Se yeast $(3 \mathrm{mg} /$ heifer/d until calving). Heifers supplemented with barium selenate had a higher glutathione peroxidase activity from $14 \mathrm{~d}$ in milk onwards. Selenium supplementation, irrespective of source, tended to reduce the prevalence of intramammary infection (IMI) and decrease the prevalence of quarters with high somatic cell count (SCC) at calving. Overall, Se supplementation did not result in a reduction of the incidence of new IMI or clinical mastitis or in decreased SCC during the balance of the first month of lactation. However, in pasture-based heifers injected with barium selenate before calving, and fed diets with 1.3 and $2.5 \mathrm{mg}$ of Se/d precalving and during lactation,

Received January 15, 2010.

Accepted June 2, 2010.

${ }^{1}$ Corresponding author: alejandro.ceballos@ucaldas.edu.co respectively, no cases of clinical mastitis were observed in the first month of lactation.

Key words: dairy heifer, selenium, udder health, intramammary infection

\section{INTRODUCTION}

Heifers should be at low risk for IMI at first calving, as they produce less milk, have not experienced multiple daily milkings, have less exposure to contagious pathogens, and are less likely to be in contact with the environment (Fox, 2009). However, a wide variation in the immediate postpartum prevalence of IMI has been reported in quarters of first-calving heifers, ranging from 12 to over $57 \%$, with CNS being the most prevalent pathogens associated with IMI (Compton et al., 2007; Fox, 2009; Piepers et al., 2010). The incidence of clinical mastitis (CM) may reach $35 \%$ during the peripartum period (Fox, 2009). The peak incidence may be higher than that found in multiparous cows, with $>30 \%$ of cases in first-lactation heifers occurring during the first 14 DIM (Barkema et al., 1998; Olde Riekerink et al., 2008; Sampimon et al., 2009). Yet, the prevalence and incidence of IMI and CM in peripartum heifers varies greatly between management systems (Fox, 2009), suggesting that management interventions at the farm level may be useful in reducing the risk of these infections.

Many important risk factors are associated with subclinical mastitis and CM in heifers. Links between nutrition and mastitis control, in particular with respect to the micronutrients Se and vitamin E, have been studied extensively (Smith et al., 1997; Heinrichs et al., 2009). Providing insufficient Se in dairy cow rations results in a reduced concentration of Se in blood and milk (Maus et al., 1980), downregulation of the expression of glutathione peroxidase $(\mathbf{G P x})$ and other antioxidants with roles in the defense of the mammary gland (Sordillo et al., 2007), decreased bactericidal 
capacity of neutrophils, and inhibited lymphocyte proliferation (Grasso et al., 1990) that, acting together, are believed to impair the immune response of the udder to pathogens.

In a North American study, supplementation of heifers with Se resulted in a lower prevalence of IMI at calving, lower incidence of CM, shorter duration of IMI, and lower SCC (Smith et al., 1985). The estimated equivalent Se intake for those heifers was beyond the current recommendation for dairy cows, which is $3 \mathrm{mg} /$ $\mathrm{kg}$ of total ration DM (NRC, 2001). However, studies in pasture-based dairy cows in New Zealand have found no relationship between Se supplementation and udder health, as measured by SCC (Whelan et al., 1992; Wichtel et al., 1994; Grace et al., 1997). In support of these findings, a recent trial conducted in southern Chile, where a long-acting Se supplement was administered at drying off to moderately Se-deficient pastured dairy cows resulted in a sustained increase in blood GPx activity. However, no change was found in the incidence of new IMI or SCC during the subsequent lactation (Ceballos et al., 2010), suggesting that the Se requirement for optimal immune function in dairy cows under pastoral systems may be lower than the current NRC (2001) recommendation for cows raised in intensive systems. These findings suggest that the response to Se supplementation in measures of udder health may differ depending on the system under which the experimental animals are managed.

Uniform, reliable delivery of mineral supplements to cattle is a challenge under pastoral conditions; freechoice feeding of mineral supplements often results in intake that is inconsistent within and between animals in the herd. A single injection of a slow-release form of Se (e.g., barium selenate) provides not only a long duration of effect but also an appropriate daily delivery of Se, suitable for correcting deficiency in ruminants under most pastoral systems (Mallinson et al., 1985). This form is particularly useful in pastured cattle because it needs to be administered only once per lactation, ideally before calving, and does not depend on a system for feeding a Se-fortified concentrate ration. Selenium can be also supplemented to cattle diets incorporating organic forms to concentrates. Cattle fed Se yeast usually have a higher blood Se concentration and higher GPx activity in blood (Malbe et al., 1995) and milk (Ceballos et al., 2009) than do those supplemented with inorganic sources. However, most studies that found a beneficial role of Se on measures of udder health used sodium selenate or selenite as Se source. It is unknown whether the typically higher GPx activity (i.e., improved Se status) when cows are injected with barium selenate or fed Se yeast reflects an improved udder health compared with supplementation using traditional inorganic sources (e.g., sodium selenite). We hypothesized that Se supplementation before calving may be associated with a lower risk of new IMI and SCC around calving in heifers grazing low-Se pastures.

The objectives of this study were to determine the effects of precalving Se supplementation and type of supplementation (injectable barium selenate vs. oral Se yeast) on the blood activity of GPx and measures of udder health immediately after calving and during the first month of lactation in pastured dairy heifers.

\section{MATERIALS AND METHODS}

All procedures for this trial complied with current regulations for the humane care and treatment of animals, and the Commission for Animal Care and Use of the Universidad Austral de Chile.

\section{Animals and Treatments}

The trial was carried out on 4 commercial dairy farms in southern Chile $\left(39^{\circ} 46^{\prime} \mathrm{S}, 73^{\circ} 13^{\prime} \mathrm{W}\right)$ where prior tests had revealed marginal Se concentration in pastures $(\sim 0.1 \mathrm{mg} / \mathrm{kg}$ of DM), and herd-level analyses of blood GPx activity had indicated a mean $\leq 100 \mathrm{U} / \mathrm{g}$ of hemoglobin $(\mathbf{H b})$, consistent with suboptimal Se intake using a published reference range for blood GPx in Chilean cattle (Ceballos et al., 1999).

One hundred forty pregnant Chilean Holstein-Friesian heifers that were predicted to calve approximately $45 \mathrm{~d}$ after the day of treatment were selected for the study. Heifers on each farm (farm 1, n $=26$; farm 2, n $=33$; farm $3, \mathrm{n}=35$; farm $4, \mathrm{n}=46$ ) were randomly allocated to 1 of 3 treatments by a systematic random process. Briefly, the first heifer being run through a chute was assigned to the control group, the second to treatment group 1, and the third heifer to treatment group 2, repeating the sequence with the subsequent animals. Group $1(\mathrm{n}=49)$ received no supplementary Se; Se consumption corresponded to the basal intake for the herd. Heifers in group $2(\mathrm{n}=46)$ received a single subcutaneous injection of a $1 \mathrm{mg}$ of Se/ $\mathrm{kg}$ of live weight as barium selenate (Deposel, Young Animal Health Ltd., Wellington, New Zealand). Heifers in group 3 (n $=45$ ) were fed $3 \mathrm{mg}$ of Se/heifer per day as Se yeast (Sel-Plex, Alltech, Nicholasville, KY) carried in $250 \mathrm{~g}$ of wheat hulls, from the first day of treatment until calving. All heifers were maintained on pasture under similar farm management conditions and were fed the same ration for close up and lactation (Table 1).

Heifers calved within an 11-wk period in the Southern Hemisphere winter and spring (i.e., mid July to mid October of 2007). Calves were removed from their dams within $1 \mathrm{~d}$ after birth. Heifers were milked twice daily 
Table 1. Average composition of the close up and lactation diets (\% of ration DM), mean and range of selenium concentration of the components, total daily Se intake (mg/heifer per d), and suggested Se intake for each physiological status

\begin{tabular}{lccc}
\hline Item & Close up & Lactation & $\begin{array}{c}\text { Se, } \mathrm{mg} / \mathrm{kg} \text { of DM } \\
\text { (range) }\end{array}$ \\
\hline $\begin{array}{l}\text { Ingredient, \% of DM } \\
\text { Grass }\end{array}$ & 52.3 & 22.4 & $0.10(0.02,0.16)$ \\
Grass silage or hay $^{1}$ & 14.5 & 33.0 & $0.09(0.02,0.14)$ \\
Concentrate $^{2}$ & 32.2 & 43.3 & $0.10(0.05,0.10)$ \\
$\quad$ Mineral mix & 1.0 & 1.3 & $12.0(11.0,15.0)$ \\
Selenium intake, mg/heifer per d & & & \\
$\quad$ Actual & 1.3 & 2.5 & \\
Intensive dairy systems (NRC, 2001) $_{\text {Pastoral dairy systems (Grace, 1992) }}$ & 2.7 & 4.7 & \\
\hline
\end{tabular}

${ }^{1}$ Before calving, grass silage was fed to heifers in 3 herds and grass hay in 1 herd.

${ }^{2}$ Selenium as sodium selenite.

starting $1 \mathrm{~d}$ after calving. Milk yield was recorded at the end of the 28-d study period. Mastitis management included regular monitoring of milking machine function, postmilking teat disinfection, antibiotic treatment of clinical cases, and antibiotic treatment of all cows at drying-off. Before and after calving, the animals comprising the 3 experimental groups (within herd) were separated from each other and grazed perennial ryegrass (Lolium perenne) and white clover (Trifolium repens). The same pastures were used to make silages and hays on each farm. Heifers were moved daily onto fresh pasture, and were fed with a close-up diet consisting of supplemental silage or hay, commercial concentrates, and mineral mixes for the last $3 \mathrm{wk}$ of gestation. After calving, animals were still on pasture and supplemented with silage, concentrates, and mineral mixes (Table 1). The daily amount of concentrate offered per heifer was, on average, $1 \mathrm{~kg} / 4 \mathrm{~kg}$ of milk yield. Mineral mixes were offered at a rate of 200 to $400 \mathrm{~g} /$ head per day. Supplements, concentrates, and mineral mixes contained Se as sodium selenite. Water was offered ad libitum. Animals did not receive any other treatment that could affect their Se status.

Daily DMI was, on average, 9.0 and $15.5 \mathrm{~kg} / \mathrm{d}$ for the close-up and lactation diets, respectively. The effective amount of basal Se delivered to the heifers via the basal diet, on a per day basis, was estimated as the average of the Se concentration of the components weighted by the average DMI of each component (Table 1). The basal Se intake was approximately $50 \%$ of the recommended amount for close-up and fresh heifer rations (NRC, 2001). The effective amount of Se delivered to the heifers via the depot injection of barium selenate was estimated to be, on average, $0.8 \mathrm{mg}$ of $\mathrm{Se} / \mathrm{d}(95 \%$ CI: $0.28,1.27 \mathrm{mg}$ of Se/d) in heifers (Mallinson et al., 1985). Mallinson et al. (1985) arrived at this estimate by measuring the residual barium selenate at the site of injection 17 wk after treatment; however, this is likely to be an underestimate of the daily payout in the weeks immediately after injection.

\section{Sampling and Data Collection}

Milkers on each farm were trained to collect milk samples aseptically from quarters that had physical signs of CM (any visual abnormality of milk or udder, with or without systemic signs of disease). The first streams of milk were squirted onto a dark cup to detect any abnormality such as discoloration, flakes, clots, or wateriness. This physical examination of the udder and milk characteristics was conducted at calving and at every milking to detect individual quarters affected by CM.

After removing 2 streams of milk and disinfection with a cotton swab soaked in $70 \%$ isopropyl alcohol, milk samples $(15 \mathrm{~mL})$ for bacteriological analysis were aseptically collected from every quarter by an experienced veterinarian or technicians on the day of calving, and thereafter at 1, 7, 14, 21 and 28 DIM. Immediately after collection, samples were refrigerated at $5{ }^{\circ} \mathrm{C}$ for transportation to the laboratory. Quarter foremilk and milk samples $(\sim 30 \mathrm{~mL})$ were also collected in vials with potassium dichromate for SCC determination. Samples were kept refrigerated and analyzed within $24 \mathrm{~h}$.

A batch of 1,053 (31\%) milk samples that included samples from all farms, heifers, and quarters was lost after a fire destroyed the laboratory of microbiology of the Faculty of Sciences of the Universidad Austral de Chile (Appendix).

Coccygeal venous blood samples were collected from control and treated heifers at the beginning of treatment, and 14 and 28 DIM into heparinized vials to determine blood GPx activity.

\section{Laboratory Analyses}

Bacteriological examination was performed according to the standards of the National Mastitis Council 
(Oliver et al., 2004). An esculin blood (sheep) agar plate was divided and $0.05 \mathrm{~mL}$ of milk was streaked onto one half; the plate was left at room temperature for $30 \mathrm{~min}$ and then aerobically incubated at $37^{\circ} \mathrm{C}$ and examined after 24 and $48 \mathrm{~h}$. For each half of the plate, the number of colonies was expressed as cfu/0.05 mL. A single well-isolated colony was subcultured for bacterial species identification according to colony morphologic features, hemolytic characteristics, and Gram stain reaction. Species presumptively identified as staphylococci were tested by the catalase test, tube coagulase method, and deoxyribonuclease (DNase) degradation test in DNase agar plates. Staphylococcus aureus was identified by positive catalase, coagulase reaction, and DNase tests. The CNS were identified by a negative coagulase reaction and a negative DNase test. Catalase reaction and the Christie, Atkins, Munch-Petersen test were set up for the classification of isolates presumptively identified as streptococci. When necessary, the SVA Strep was used to classify streptococci according to their biochemical properties (SVA Strep, SVA, Uppsala, Sweden). Gram-negative isolates were classified as Escherichia coli when negative to the oxidase test and positive to the production of $\beta$-D-glucuronidase and indole (PI Test, SVA). Strains that were negative were further tested by the API20E identification system (bioMérieux SA, Marcy l'Etoile, France), which permits rapid species identification of Enterobacteriaceae and other gram-negative organisms (Oliver et al., 2004).

Milk SCC was determined using a Combifoss 5300 cell counter (Foss Electric, Hillerød, Denmark). Data were expressed as natural logarithm of SCC in thousands per milliliter (LnSCC) to approximate the normal distribution; LnSCC was backtransformed for presentation purposes.

Selenium in pasture and concentrate was evaluated by the hydride generation atomic absorption spectrometry method (Clinton, 1977) and expressed in milligrams per kilogram of DM.

The Se status of heifers was evaluated through the activity of GPx by a kinetic method (Ransel, Randox Laboratories, Crumlin, UK). This selenoenzyme is a biomarker of Se status and its activity was measured using the method of Paglia and Valentine (1967) with slight modifications (Ceballos et al., 1999). Briefly, hemoglobin in fresh blood was measured by the cyanomethemoglobin method before GPx analysis. The enzyme activity is proportional to the decrease in absorption at $340 \mathrm{~nm}$ after the oxidation of NADPH into NADP. Results are expressed in units per gram of hemoglobin, considering an activity $<100 \mathrm{U} / \mathrm{g} \mathrm{Hb}$ to be indicative of suboptimal Se status (Ceballos et al., 1999).

\section{Definition of IMI}

A quarter was considered to have an IMI at calving when $\geq 1 \mathrm{cfu} / 0.05 \mathrm{~mL}$ (equivalent to $\geq 20 \mathrm{cfu} / \mathrm{mL}$ ) of a pathogen was obtained from foremilk samples collected at calving and $1 \mathrm{~d}$ after. An IMI in the 28 -d period after calving was established when a pathogen was cultured, as described above, in 2 out of 3 consecutive samples (i.e., among 7, 14, and 21 DIM or among 14, 21, and 28 DIM after calving). A quarter with an IMI at calving was considered cured for a pathogen if the sample was free of the pathogen in question on at least 2 consecutive tests during the 28-d study period (Ceballos et al., 2010, with slight modifications). An IMI established after calving was considered as a new IMI if the quarter did not have an IMI at calving (for the pathogen in question) or if an IMI at calving was cured before the (new) IMI was established. Samples containing more than 2 bacterial species were considered contaminated and were not informative of IMI status.

\section{Statistical Analysis}

Glutathione Peroxidase. The repeated measurements of GPx (beginning of treatment, 14, and 28 DIM) of each heifer were analyzed using linear mixed models (Dohoo et al., 2009). An unstructured correlation structure for the dependence within a series of observations for blood GPx activity within a cow was evaluated. The model furthermore included fixed categorical effects of herd, treatment group, time (days), and the interaction of treatment and time. Because of the significant interaction of treatment and time, effects of treatment were evaluated at each time point using $F$-tests, and effects of time were evaluated similarly within each treatment group. Furthermore, model-based pairwise comparisons between all treatment by time combinations were carried out with a Bonferroni adjustment for multiple testing.

Incidence Risk of New IMI and Clinical Mastitis. The prevalence of IMI at calving was calculated as the number of IMI divided by the number of quarters sampled at that specific time. A logistic regression model combined with generalized estimating equations (GEE) to account for within-heifer clustering (exchangeable correlation structure) was used to evaluate any differences between unsupplemented control heifers and Se-supplemented heifers while including fixed effects of herds. The coefficients of the regression model were expressed as population-averaged odds ratios (OR), which gives the effect of Se supplementation on having an IMI at calving across all heifers (Dohoo et al., 2009). Assuming that missing values were missing completely 
at random, they should not introduce any biases in the GEE estimates values (Dohoo et al., 2009).

The incidence risk of having a new IMI was calculated as the probability that an individual quarter had a new IMI in the 28-d period after calving, considering only quarters free of IMI with the pathogen of interest at calving. The quarter was the unit of interest, and clustering within heifer was accounted for by GEE estimation in a similar logistic regression model as above and including fixed effects of herds.

Incidence of $\mathrm{CM}$ at calving and incidence of $\mathrm{CM}$ in the first month of lactation were analyzed by logistic regression models similar to the ones described above, and herd fixed effects were also included. Comparison of incidence of $\mathrm{CM}$ in the first month of lactation between unsupplemented and Se-supplemented heifers was based on likelihood-ratio following random effects logistic regression analyses, because one of the treated groups had no incident cases during that period. All analyses were carried out using the 'xtgee' and 'xtlogit' commands of Stata version 11.0 (Stata Corp., College Station, TX).

$\boldsymbol{S C C}$. The proportion of quarter samples with SCC below different cut-offs (i.e., $<150,000 ;<250,000$; $<750,000$; and $<1,000,000$ cells $/ \mathrm{mL}$ ) was calculated for each experimental group and time point (Barkema et al., 1999; Piepers et al., 2010). Geometric mean SCC of 593,000 cells $/ \mathrm{mL}$ has been found in noninfected quarters at calving (Barkema et al., 1999), whereas later in lactation a cut-off point of approximately 200,000 to 250,000 cells $/ \mathrm{mL}$ has been established as optimal to reduce diagnostic error in distinguishing between noninfected and infected quarters (Schukken et al., 2003). Therefore, the odds of having a quarter with SCC $>500,000$ and $>250,000$ cells $/ \mathrm{mL}$ at calving and after calving, respectively, was analyzed by a logistic regression model with fixed effects of supplementation, time and herd. Clustering within quarters and heifers was accounted for by the alternating logistic regression algorithm (Kleinbaum and Klein, 2002; Dohoo et al., 2009). Analyses were carried out using the GENMOD procedure of SAS version 9.2 (SAS Institute Inc., Cary, $\mathrm{NC})$.

The repeated measurements of SCC on each heifer were also analyzed using linear mixed models (Dohoo et al., 2009). A preliminary analysis of SCC revealed a large variation between data collected around the day of calving and in the 28-d study period. Consequently, 2 separate analyses were carried out for the analysis of SCC. One analysis was performed for those samples collected at calving and the day after, and the other one included the information on SCC at 7, 14, 21, and 28 DIM. The correlation structure consisted of 2 parts: unstructured correlations between quarters, and additional unstructured and first-order autoregressive correlations across the first 2 time points and the time points after calving, respectively. Fixed effects of herd, treatment group, time, and their interactions were included. All models were evaluated by examining the standardized residuals, and Box-Cox transformations of the outcome were explored whenever the model assumptions were not fully met. The final analysis was carried out on natural $\log$ scale for SCC at calving, and on a power-transformed scale for SCC in the 28-d study period; all estimates were converted to LnSCC and backtransformed to SCC for presentation purposes. The linear mixed model analysis for GPx and LnSCC were carried out using the MIXED procedure of SAS version 9.2 (SAS Institute Inc.).

\section{RESULTS}

The mean interval from the beginning of the study to calving was 30 (95\% CI: 25, 36), and 33 (95\% CI: $29,36) \mathrm{d}$ in the unsupplemented control heifers and Se-supplemented heifers, respectively. In unsupplemented control heifers, average milk yield at 28 DIM (end of the study period) was $23.4 \pm 0.9 \mathrm{~kg}$, whereas Se-supplemented heifers produced $1.2 \pm 0.9 \mathrm{~kg}$ more milk. Analysis by contrasts in a linear model (including also herd effects) revealed that the difference between control and supplemented heifers was not significant $(P$ $=0.20)$, nor was there a significant difference between the 2 Se sources $(P=0.78)$.

Mean blood GPx activity was similar among groups at the beginning of treatment $(P=0.14)$. Selenium treatment, time after treatment, and their interaction had a significant effect on blood GPx activity $(P=$ 0.02). Mean blood GPx activity was significantly higher in heifers treated with barium selenate than in unsupplemented controls and heifers fed Se yeast at 14 DIM (Figure 1) and significantly higher than controls at 28 DIM. No differences in Se status between unsupplemented heifers and heifers fed Se yeast were observed (Figure 1). Blood GPx activity also increased significantly over time in all groups until the end of the study, and was $116 \mathrm{U} / \mathrm{g}$ of $\mathrm{Hb}$ (95\% CI: $65,167 \mathrm{U} / \mathrm{g}$ of $\mathrm{Hb}$ ) higher in the heifers treated with barium selenate compared with the mean activity in unsupplemented controls, and $74 \mathrm{U} / \mathrm{g}$ of $\mathrm{Hb}(95 \% \mathrm{CI}: 23,125)$ higher than the mean activity in the heifers fed Se-yeast at 28 DIM (Figure 1).

\section{IMI and Clinical Mastitis}

The effect of Se supplementation on IMI was evaluated on 1,846 ( $55 \%$ of the original data set) remaining samples, as 1,053 were lost and 461 did not match the criteria to establish an IMI. 
Table 2. Quarter-level prevalence of IMI and incidence of clinical mastitis at calving, number of cured quarters, and new infections and clinical mastitis cases in the first month of lactation in pasture-based primiparous heifers supplemented with selenium before calving and unsupplemented control heifers ${ }^{1}$

\begin{tabular}{|c|c|c|c|c|c|c|c|c|c|}
\hline \multirow[b]{2}{*}{ Pathogen } & \multicolumn{3}{|c|}{ Unsupplemented } & \multicolumn{3}{|c|}{ Barium selenate } & \multicolumn{3}{|c|}{ Se yeast } \\
\hline & $\mathrm{C}$ & Cured & $\mathrm{L}$ & $\mathrm{C}$ & Cured & $\mathrm{L}$ & $\mathrm{C}$ & Cured & $\mathrm{L}$ \\
\hline Staphylococcus aureus & 0 & 0 & 0 & 0 & 0 & 1 & 0 & 0 & 1 \\
\hline Streptococcus dysgalactiae & 0 & 0 & 1 & 0 & 0 & 0 & 1 & 0 & 0 \\
\hline Streptococcus uberis & 1 & 0 & 0 & 1 & 0 & 0 & 0 & 0 & 0 \\
\hline Escherichia coli & 4 & 4 & 0 & 0 & 0 & 0 & 0 & 0 & 0 \\
\hline CNS & 17 & 14 & 2 & 8 & 6 & 4 & 12 & 11 & 8 \\
\hline Other pathogens & 4 & 0 & 0 & 0 & 0 & 1 & 1 & 0 & 1 \\
\hline Total & 26 & 18 & 3 & 9 & 6 & 6 & 14 & 11 & 10 \\
\hline Clinical mastitis cases & 4 & - & 6 & 4 & - & 0 & 3 & - & 7 \\
\hline Total quarters at risk ${ }^{2}$ & 126 & - & 102 & 83 & - & 83 & 118 & - & 113 \\
\hline
\end{tabular}

${ }^{1}$ Only quarters with complete set of samples were included; $\mathrm{C}=$ number of quarters with an IMI at calving; Cured = number of cured quarters that had an IMI at calving; L = number of quarters with new IMI in the first 28 DIM.

${ }^{2}$ Number of quarters with new IMI in the first 28 DIM.

A total of 780 quarter foremilk samples collected at calving were cultured. Bacterial growth occurred in 209 samples (27\%), 81 samples were contaminated (10\%), and a pathogen could not be classified in 8 samples (1\%). Coagulase-negative staphylococci were the most frequently isolated group of bacteria (70\%), followed by Escherichia coli (9\%) and Streptococcus uberis (6\%). Prevalence of IMI across heifers at calving tended to be lower in Se-supplemented heifers compared with unsupplemented controls (OR: $0.5 ; 95 \%$ CI: $0.2,1.2)$. No differences were observed among herds $(P=0.82)$.

The proportion of infected quarters at calving that cured was 69 and $74 \%$ for unsupplemented and Se-

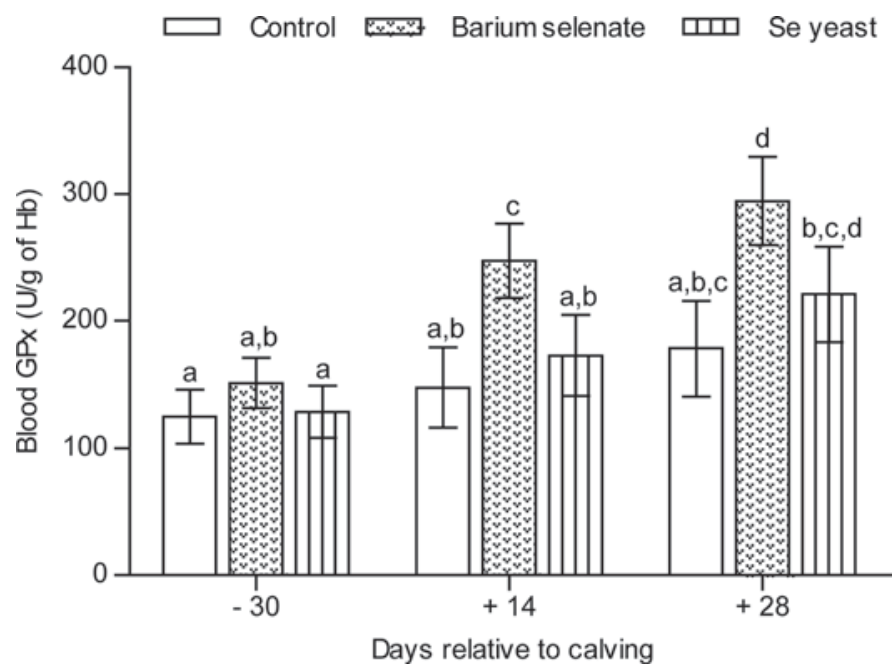

Figure 1. Least squares means with SE of blood glutathione peroxidase $(\mathrm{GPx}, \mathrm{U} / \mathrm{g}$ of $\mathrm{Hb}$ ) activity in unsupplemented pastured heifers $(\mathrm{n}=49)$ or heifers supplemented with barium selenate $(\mathrm{n}=46)$ and Se yeast $(\mathrm{n}=45) 1$ mo before calving. ${ }^{\mathrm{a}-\mathrm{d}}$ Means with different letters differ significantly (adjusted $P<0.05$ ). supplemented heifers, respectively. However, the odds of cure were not significantly different among treatment groups (OR: 1.5; 95\% CI: 0.2, 13.2). Quarters infected with Strep. uberis and other pathogens at calving did not cure over the study period (Table 2), whereas CNS IMI at calving lasted $16 \mathrm{~d}$ on average, ranging from 14 d to $28 \mathrm{~d}$.

A total of 1,066 quarter milk samples collected during the 28-d study period after calving were cultured, and bacterial growth was found in 172 samples (16\%). Seventy-four samples $(7 \%)$ were contaminated, and a pathogen could not be classified in 21 samples $(2 \%)$. The most common isolated pathogens were CNS (63\%); Staph. aureus, Streptococcus dysgalactiae, and Strep. uberis were isolated in $16 \%$ of the samples. Twenty-six IMI were found in the 28-d study period, and 19 of them were considered new IMI. Even though new IMI were numerically higher in Se-supplemented heifers, supplementation did not significantly increase the overall odds of having a new IMI in the 28-d study period (OR: $2.2 ; 95 \%$ CI: $0.7,7.4$ ). No new IMI were found in one of the herds after calving; also, in the remaining herds, the odds of having a new IMI after calving differed among herds $(P=0.02)$. Because of the low number of new infections, the pathogen-specific effect of supplementation could be assessed only for CNS and did not show any statistical significance (OR: 2.5; $95 \%$ CI: $0.6,11.4)$.

Eleven cases of $\mathrm{CM}$ were detected at calving, of which 4 occurred in the unsupplemented control heifers and 7 in the Se-supplemented groups (OR: 1.1; 95\% CI: $0.2,6.4)$. During the first month of lactation, 13 new cases were detected, 6 of which occurred in the unsupplemented heifers, no new cases were found in the barium selenate group in the 28 -d study period, and 7 


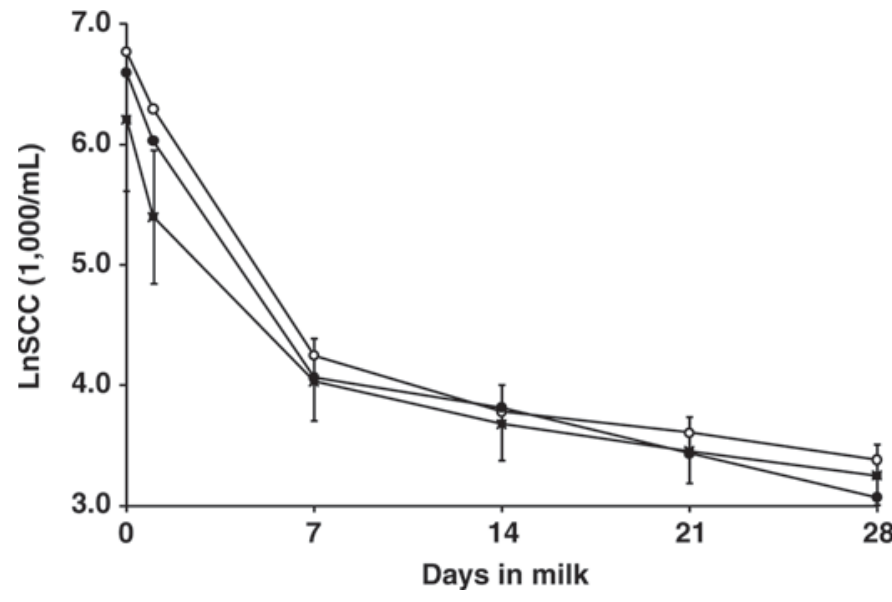

Figure 2. Model-based estimated SCC (LnSCC) in milk in pastured heifers, which were either unsupplemented $(\mathrm{O}, \mathrm{n}=49)$ or supplemented with barium selenate $(\boldsymbol{\square}, \mathrm{n}=46)$ or selenium yeast $(\boldsymbol{\bullet}, \mathrm{n}=$ 45) 1 mo before calving. For clarity, $95 \%$ CI bars are shown only for the barium selenate group.

occurred in the Se yeast group (Table 2). Incidence of $\mathrm{CM}$ tended to be lower in the barium selenate-treated group compared with the unsupplemented heifers and the Se yeast-treated heifers after a Bonferroni adjustment $(P=0.06)$.

\section{$\operatorname{sCC}$}

A total of 998 quarter foremilk samples collected at calving and $1 \mathrm{~d}$ after and 2,108 quarter milk samples collected between 7 and 28 DIM were analyzed for SCC. The proportion of quarters with SCC below the different cut-offs at and after calving in the treatment groups is presented in Table 3. Geometric mean SCC decreased from 682,000 cells $/ \mathrm{mL}$ at calving to 368,000 cells/mL $1 \mathrm{~d}$ after calving $(P<0.001)$, and then gradually decreased until the end of the 28-d follow-up period $(P<0.001$; Figure 2). Selenium supplementation, regardless of Se source, tended to reduce SCC $1 \mathrm{~d}$ after calving $(P=0.08$; Figure 2$)$. However, there was no effect of supplementation on LnSCC during the 28-d period after calving $(P=0.48$; Figure 2$)$.

A significant reduction in the odds of having a quarter with $\mathrm{SCC}>500,000$ cells $/ \mathrm{mL}$ at calving was found in Se-supplemented heifers compared with unsupplemented controls (Table 4). However, Se supplementation did not affect the odds of having a quarter with SCC $>250,000$ cells/mL during the $28-\mathrm{d}$ after calving. The odds of a quarter having a SCC below the selected cut-off points differed among herds at calving, and after calving (Table 4).

\section{DISCUSSION}

Blood GPx activity increased over time in Se-supplemented heifers and was higher in heifers supplemented with barium selenate. Selenium supplementation also tended to decrease the prevalence of IMI and average SCC at calving; however, no differences were found in the incidence risk of new IMI or SCC among groups in the 28-d follow-up period after calving.

A higher blood GPx activity was found in barium selenate-treated heifers from 30 to $45 \mathrm{~d}$, concurring with previous studies (Mallinson et al., 1985; Grace et al., 2001). However, Se incorporation into GPx structure during erythropoiesis is a slow process (Grace et al., 2001). Thus, a lag in the rate of change in blood GPx activity occurs following changes in dietary Se intake (Thompson et al., 1981; Grace et al., 2001). Our first blood GPx analyses, averaging $135 \mathrm{U} / \mathrm{g}$ of $\mathrm{Hb}$, reflected the dietary Se intake before the beginning of the study, and this level was considered adequate based on Chilean reference ranges (Ceballos et al., 1999). Further analyses at 14 and 28 DIM reflected an increase in basal intake due to supplementation of close-up diets with concentrates and mineral mixes. No differences in blood GPx activity were found between heifers fed Se yeast and unsupplemented control heifers. Other studies have found that Se sources may be metabolized in a different way, noting that Se yeast is nonspecifically

Table 3. Percentage of quarters with SCC below different cut-off points according to DIM in pasture-based primiparous heifers supplemented with selenium before calving and in unsupplemented controls ${ }^{1}$

\begin{tabular}{|c|c|c|c|c|c|c|c|c|c|c|c|c|}
\hline \multirow[b]{3}{*}{ DIM } & \multicolumn{12}{|c|}{$\mathrm{SCC}, \times 1,000$ cells $/ \mathrm{mL}$} \\
\hline & \multicolumn{3}{|c|}{$<150$} & \multicolumn{3}{|c|}{$<250$} & \multicolumn{3}{|c|}{$<500$} & \multicolumn{3}{|c|}{$<1,000$} \\
\hline & $\mathrm{C}$ & $\mathrm{BS}$ & Se Y & $\mathrm{C}$ & $\mathrm{BS}$ & Se $Y$ & $\mathrm{C}$ & $\mathrm{BS}$ & Se Y & $\mathrm{C}$ & $\mathrm{BS}$ & Se Y \\
\hline 0 & 20 & 30 & 26 & 30 & 32 & 36 & 40 & 51 & 50 & 53 & 57 & 58 \\
\hline 1 & 27 & 41 & 34 & 38 & 50 & 44 & 49 & 65 & 59 & 61 & 73 & 68 \\
\hline 7 & 70 & 69 & 73 & 80 & 80 & 78 & 90 & 86 & 86 & 94 & 89 & 89 \\
\hline 14 & 77 & 74 & 76 & 86 & 89 & 89 & 91 & 92 & 95 & 93 & 94 & 96 \\
\hline 21 & 77 & 82 & 81 & 84 & 91 & 92 & 90 & 94 & 96 & 94 & 96 & 98 \\
\hline 28 & 77 & 77 & 84 & 88 & 87 & 94 & 93 & 94 & 99 & 96 & 96 & 99 \\
\hline
\end{tabular}

${ }^{1} \mathrm{C}=$ control group; $\mathrm{BS}=$ barium selenate group; Se $\mathrm{Y}=$ selenium yeast group. 
Table 4. Multivariable regression model of the effect of selenium (Se) supplementation, sampling time, and herd on the prevalence of quarters with SCC $>500,000$ cells $/ \mathrm{mL}$ at calving, and SCC $>250,000$ cells $/ \mathrm{mL}$ in the first 28 DIM in pasture-based primiparous heifers supplemented with selenium before calving and unsupplemented controls

\begin{tabular}{|c|c|c|c|}
\hline Group & Odds ratio & $95 \% \mathrm{CI}$ & $P$-value \\
\hline \multicolumn{4}{|c|}{$\mathrm{SCC}>500,000$ cells $/ \mathrm{mL}$ at calving } \\
\hline Treatment & & & 0.04 \\
\hline Unsupplemented & 1 & & \\
\hline Se-supplemented & 0.6 & $0.3,1.0$ & \\
\hline Herd & & & 0.02 \\
\hline 1 & 1.5 & $0.7,3.0$ & \\
\hline 2 & 0.5 & $0.2,0.9$ & \\
\hline 3 & 0.7 & $0.4,1.3$ & \\
\hline 4 & 1 & & \\
\hline Sampling (DIM) & & & $<0.01$ \\
\hline 0 & 1 & & \\
\hline 1 & 0.6 & $0.5,0.8$ & \\
\hline \multicolumn{4}{|c|}{$\mathrm{SCC}>250,000$ cells $/ \mathrm{mL}$ at $7-28 \mathrm{DIM}$} \\
\hline Treatment & & & 0.20 \\
\hline Unsupplemented & 1 & & \\
\hline Se-supplemented & 0.7 & $0.5,1.2$ & \\
\hline Herd & & & $<0.01$ \\
\hline 1 & 0.5 & $0.2,1.1$ & \\
\hline 2 & 1.6 & $1.0,2.8$ & \\
\hline 3 & 2.5 & $1.3,4.6$ & \\
\hline 4 & 1 & & \\
\hline Sampling (DIM) & & & $<0.01$ \\
\hline 7 & 1 & & \\
\hline 14 & 0.5 & $0.3,0.8$ & \\
\hline 21 & 0.5 & $0.3,0.7$ & \\
\hline 28 & 0.4 & $0.3,0.7$ & \\
\hline
\end{tabular}

incorporated into selenoproteins (Awadeh et al., 1998); however, selenomethionine from Se yeast can be incorporated into other proteins (e.g., casein) replacing methionine. Consequently, supplementing Se as Se yeast does not necessarily result in a concurrent increase in blood GPx activity.

Prevalence of IMI tended to be lower at calving in Sesupplemented heifers compared with unsupplemented controls. Selenium supplementation was highly protective at calving in first-lactation heifers in an intensively managed North American herd, reducing the prevalence of staphylococcal IMI by $42 \%$ (i.e., $91 \%$ of these were CNS, and the rest were Staph. hyicus or Staph. intermedius), whereas no differences in the prevalence of streptococci IMI and E. coli IMI were found (Smith et al., 1985). Notwithstanding, heifers in the trial of Smith et al. (1985) were fed a supranutritional Se intake compared with the current NRC (2001) recommendation. Achieving a Se intake close to NRC (2001) recommendation in dairy cattle from Southern Chile would be unlikely because of low Se concentrations in pastures and crops; therefore, heifers in our study received a lower equivalent Se intake than that reported in other studies (Smith et al., 1985; Malbe et al., 1995).

The slight effect of Se supplementation on IMI at calving and on CM after calving, and in particular the absence of incident $\mathrm{CM}$ cases in heifers injected with barium selenate, can be linked by several factors. Mineral supplementation, particularly with Se, enhances leukocyte function and the mammary immune response to bacteria (Hogan et al., 1990; Piepers et al., 2009), now thought to be mediated through the expression of selenoproteins with antioxidant properties (Sordillo et al., 2007). Glutathione peroxidase reduces lipid hydroperoxides generated during the respiratory burst, protecting leukocytes from killing themselves (Sordillo et al., 2007). In addition, Se supplementation enhances the production of chemoattractants and influx of PMNL into the udder (Erskine et al., 1989), favors the production of inflammation mediators (Cao et al., 1992), and enhances the bactericidal capacity of the neutrophils (Gyang et al., 1984; Erskine et al., 1989), all of which explain a tendency toward lower prevalence of infection at calving and rapid elimination of IMI in Se-supplemented animals. No incident CM cases in the first month after calving in heifers injected with barium selenate might be the result of differences in the incorporation of Se into selenoproteins with antioxidant properties, which requires further study. As mentioned, there are metabolic differences among Se sources (Awadeh et al., 1998).

The lack of effect of Se supplementation on the incidence of IMI can be partially explained by the power of the study; there was sufficient power to detect a $40 \%$ 
change in the risk of new IMI between groups, which is a relatively large effect. Second, Se status was considered adequate when the study started. However, blood GPx activity at the beginning of the study was within the range at which we previously found a beneficial effect of Se supplementation on udder health (Kruze et al., 2007). A third reason could be that the basal Se intake, as indicated by an increase in blood GPx even in the unsupplemented controls, was not constant over the study period due to feeding concentrates and mineral mixes before calving.

Pathogen-specific differences in the immune response of the udder of Se-supplemented heifers may be another factor that explains the lack of a beneficial effect of Se on the risk of new IMI in the first month of lactation. A massive and rapid influx of PMNL to the udder was found in Se-supplemented cows after E. coli IMI (Erskine et al., 1989), whereas the PMNL influx was slower in Staph. aureus IMI (Erskine et al., 1990). However, PMNL were more efficient in killing Staph. aureus in Se-supplemented cows compared with unsupplemented controls (Erskine et al., 1990). In addition, the inflammatory response to CNS IMI was less pronounced than the response to IMI caused by major pathogens (Barkema et al., 1999). In our study, however, the prevalence and incidence of Staph. aureus and CNS IMI were lower than reported in previous studies.

The association between nutrients other than Se and the udder immune response may also explain our results. Even though plasma tocopherol values decrease by $50 \%$ at the beginning of lactation, values start to increase after 20 DIM (Weiss et al., 1990), and cows raised in pastoral systems will typically experience more than sufficient intake of vitamin $\mathrm{E}$ when fresh forage is fed (Weiss, 1998). The higher vitamin E intake appears to have a sparing effect on Se requirement (Wichtel, 1998); however, this relationship has not been precisely quantified (NRC, 2001). A low incidence of Se-responsive disorders, such as subclinical or clinical mastitis, under pastoral conditions may be the result of high concentrations of vitamin $\mathrm{E}$ in pasture (Wichtel, 1998). This profile is explained by changes in DMI in the periparturient period. Peer-reviewed literature concerning the dynamics of IMI in unsupplemented and Se-unsupplemented cows under pastoral conditions comparable to those of our study is scarce. However, similar results were found in a trial conducted in southern Chile that enrolled primiparous and multiparous cows, where Se supplementation with barium selenate before calving did not affect the risk and rate of new IMI during the subsequent lactation (Ceballos et al., 2010).

Somatic cell count is elevated shortly after calving even in the absence of IMI, declining rapidly in the first
6 milkings (Barkema et al., 1999; Piepers et al., 2010) and reaching normal levels between 2 and 4 wk of lactation (Dohoo, 1993). A relatively steep decline in mean SCC was found from calving to 7 DIM, followed by a gradual reduction from 7 DIM onward, which concurs with previous studies (Barkema et al., 1999; Sampimon et al., 2009). The postcalving decrease in SCC is the net result of a combination of the reduction in the number of false-positive elevated SCC and a decline in the prevalence of IMI (Dohoo, 1993). In our study, Se supplementation caused a reduction in the prevalence of IMI at calving, which might explain the lower SCC found in Se-supplemented heifers; however, these results did support the conclusion from early studies that found a negative relationship between Se status and SCC in milk (Smith et al., 1985; Malbe et al., 1995).

Differences in SCC after the first week of lactation have an effect on lactational SCC, milk production, and culling rate (De Vliegher et al., 2004, 2005a,b). Although SCC decreased shortly after calving in Sesupplemented heifers, geometric mean SCC was not affected by Se source, and no differences were found between unsupplemented controls and Se-supplemented heifers in the 28-d follow-up period after calving. Although the sample size was large enough to detect differences in blood GPx activity and a difference of 40,000 cells $/ \mathrm{mL}$, the data did not reflect SCC differences of this magnitude between unsupplemented controls and Se-supplemented heifers. In addition, results of North American and European studies appear to have been influenced by a limited number of herds in which the reduction of disease incidence has been reported at very high levels of supplementation, primarily CM caused by environmental pathogenic bacteria. Moreover, early studies in intensive systems had started with a higher pretreatment prevalence of IMI than that observed in our study, thus the pathogen challenge in this study might have been lower (by either type or degree) than comparable studies of intensively raised heifers and cows.

\section{CONCLUSIONS}

Selenium supplementation 1 mo before calving increased blood GPx activity, slightly reduced the prevalence of IMI at calving, and lowered SCC at the time of calving, regardless of Se source (e.g., injectable barium selenate or Se yeast). Selenium supplementation did not affect the odds of new IMI or new CM nor did it influence SCC during the balance of the first month of lactation in pastured first-lactation heifers. Nevertheless, heifers treated with barium selenate had no incident cases of $\mathrm{CM}$ in the first month of lactation. For pastoral systems in southern Chile, feeding diets 
with $<0.2 \mathrm{mg}$ of $\mathrm{Se} / \mathrm{kg}$ of $\mathrm{DM}(\sim 60 \%$ of the current NRC recommendation) appears to be effective before calving, especially for improving udder health in firstlactation heifers shortly after calving.

\section{ACKNOWLEDGMENTS}

Alltech Inc. (Nicholasville, KY) and the Direction of Research of Universidad Austral de Chile financially supported this study (Grant DID-UACH S-200752). The authors thank the owners and milkers of the dairy farms where the study was conducted, and N. Sánchez (Universidad Austral de Chile), W. Stehr (Universidad Austral de Chile), M. Palma (private practitioner), and J. González (Cooprinsem, Chile) for their support and assistance.

\section{REFERENCES}

Awadeh, F. T., M. M. Abdelrahman, R. L. Kincaid, and J. W. Finley. 1998. Effect of selenium supplements on the distribution of selenium among serum proteins in cattle. J. Dairy Sci. 81:1089-1094.

Barkema, H. W., H. A. Deluyker, Y. H. Schukken, and T. J. Lam. 1999. Quarter-milk somatic cell count at calving and at the first six milkings after calving. Prev. Vet. Med. 38:1-9.

Barkema, H. W., Y. H. Schukken, T. J. Lam, M. L. Beiboer, H. Wilmink, G. Benedictus, and A. Brand. 1998. Incidence of clinical mastitis in dairy herds grouped in three categories by bulk milk somatic cell counts. J. Dairy Sci. 81:411-419.

Cao, Y. Z., J. Maddox, A. Mastro, R. Scholz, G. Hildenbrandt, and C. Reddy. 1992. Selenium deficiency alters the lipoxygenase pathway and mitogenic response in bovine lymphocytes. J. Nutr. 122:2121-2127.

Ceballos, A., J. Kruze, H. W. Barkema, I. R. Dohoo, J. Sanchez, D. Uribe, J. J. Wichtel, and F. Wittwer. 2010. Barium selenate supplementation and its effect on intramammary infection in pasturebased dairy cows. J. Dairy Sci. 93:1468-1477.

Ceballos, A., J. Sánchez, H. Stryhn, J. B. Montgomery, H. W. Barkema, and J. J. Wichtel. 2009. Meta-analysis of the effect of oral selenium supplementation on milk selenium concentration in cattle. J. Dairy Sci. 92:324-342.

Ceballos, A., F. G. Wittwer, P. A. Contreras, E. Quiroz, and H. L. Böhmwald. 1999. (Blood activity of glutathione peroxidase and its correlation with blood selenium concentration in grazing dairy cattle). Pesquisa Agropecu. Bras. 34:2331-2338. (in Spanish)

Clinton, O. E. 1977. Determination of selenium in blood and plant material by hydride generation and atomic-absorption spectroscopy. Analyst 102:187-192.

Compton, C. W., C. Heuer, K. Parker, and S. McDougall. 2007. Epidemiology of mastitis in pasture-grazed peripartum dairy heifers and its effects on productivity. J. Dairy Sci. 90:4157-4170.

De Vliegher, S., H. W. Barkema, G. Opsomer, A. de Kruif, and L. Duchateau. 2005a. Association between somatic cell count in early lactation and culling of dairy heifers using cox frailty models. J. Dairy Sci. 88:560-568.

De Vliegher, S., H. W. Barkema, H. Stryhn, G. Opsomer, and A. de Kruif. 2004. Impact of early lactation somatic cell count in heifers on somatic cell counts over the first lactation. J. Dairy Sci. $87: 3672-3682$.

De Vliegher, S., H. W. Barkema, H. Stryhn, G. Opsomer, and A. de Kruif. 2005b. Impact of early lactation somatic cell count in heifers on milk yield over the first lactation. J. Dairy Sci. 88:938-947.

Dohoo, I. R. 1993. An evaluation of the validity of individual cow somatic cell counts from cows in early lactation. Prev. Vet. Med. 16:103-110.
Dohoo, I. R., W. Martin, and H. Stryhn. 2009. Veterinary Epidemiologic Research. 2nd ed. VER Inc., Charlottetown, Prince Edward Island, Canada.

Erskine, R. J., R. J. Eberhart, P. J. Grasso, and R. W. Scholz. 1989. Induction of Escherichia coli mastitis in cows fed selenium-deficient or selenium-supplemented diets. Am. J. Vet. Res. 50:2093-2100.

Erskine, R. J., R. J. Eberhart, and R. W. Scholz. 1990. Experimentally induced Staphylococcus aureus mastitis in selenium-deficient and selenium-supplemented dairy cows. Am. J. Vet. Res. 51:11071111.

Fox, L. K. 2009. Prevalence, incidence and risk factors of heifer mastitis. Vet. Microbiol. 134:82-88.

Grace, N. D., S. Knowles, and J. Lee. 1997. Relationships between blood Se concentrations and milk somatic cell counts in dairy cows. N. Z. Vet. J. 45:171-172.

Grace, N. D. 1992. The determination of the selenium requirements of dairy cattle. Page 106-111 in Proc. of New Zealand Trace Elements Group Conference, Palmerston North. Massey Univ., Palmerston North, New Zealand.

Grace, N. D., K. L. Ankenbauer-Perkins, A. M. Alexander, and R. M. Marchant. 2001. Relationship between blood selenium concentration or glutathione peroxidase activity, and milk selenium concentrations in New Zealand dairy cows. N. Z. Vet. J. 49:24-28.

Grasso, P. J., R. W. Scholz, R. J. Erskine, and R. J. Eberhart. 1990. Phagocytosis, bactericidal activity, and oxidative metabolism of milk neutrophils from dairy cows fed selenium-supplemented and selenium-deficient diets. Am. J. Vet. Res. 51:269-274.

Gyang, E. O., J. Stevens, W. Olson, S. Tsitsamis, and E. Usenik. 1984. Effects of selenium-vitamin E injection on bovine polymorphonucleated leukocytes phagocytosis and killing of Staphylococcus aureus. Am. J. Vet. Res. 45:175-177.

Heinrichs, A. J., S. S. Costello, and C. M. Jones. 2009. Control of heifer mastitis by nutrition. Vet. Microbiol. 134:172-176.

Hogan, J. S., K. L. Smith, W. P. Weiss, D. A. Todhunter, and W. L. Schockey. 1990. Relationships among vitamin E, selenium, and bovine blood neutrophils. J. Dairy Sci. 73:2372-2378.

Kleinbaum, D. G., and M. Klein. 2002. Logistic regression. A selflearning text. 2nd ed. Springer-Verlag, New York, NY.

Kruze, J., A. Ceballos, H. Stryhn, A. Mella, R. Matamoros, P. A. Contreras, V. Leyan, and F. Wittwer. 2007. Somatic cell count in milk of selenium-supplemented dairy cows after an intramammary challenge with Staphylococcus aureus. J. Vet. Med. A Physiol. Pathol. Clin. Med. 54:478-483.

Malbe, M., M. Klaassen, W. Fang, V. Myllys, M. Vikerpuur, K. Nyholm, S. Sankari, K. Suoranta, and M. Sandholm. 1995. Comparisons of selenite and selenium yeast feed supplements on Seincorporation, mastitis and leucocyte function in Se-deficient dairy cows. Zentralbl. Veterinarmed. A 42:111-121.

Mallinson, C. B., W. Allen, and B. Sansom. 1985. Barium selenate injections in cattle: Effects on selenium concentrations in plasma and liver and residues at site of injection. Vet. Rec. 117:405-407.

Maus, R. W., F. A. Martz, R. L. Belyea, and M. F. Weiss. 1980. Relationship of dietary selenium to selenium in plasma and milk from dairy cows. J. Dairy Sci. 63:532-537.

NRC. 2001. Nutrient Requirements of Dairy Cattle. 7th ed. Nat. Acad. Press, Washington DC.

Olde Riekerink, R. G., H. W. Barkema, D. F. Kelton, and D. T. Scholl. 2008. Incidence rate of clinical mastitis on Canadian dairy farms. J. Dairy Sci. 91:1366-1377.

Oliver, S. P., R. N. Gonzalez, J. S. Hogan, B. M. Jayarao, and W. E. Owens. 2004. Microbiological Procedures for the Diagnosis of Bovine Udder Infection and Determination of Milk Quality. 4th ed. Natl. Mastitis Counc., Verona, WI.

Paglia, D. E., and W. N. Valentine. 1967. Studies on the quantitative and qualitative characterization of erythrocyte glutathione peroxidase. J. Lab. Clin. Med. 70:158-169.

Piepers, S., G. Opsomer, H. W. Barkema, A. de Kruif, and S. De Vliegher. 2010. Heifers infected with coagulase-negative staphylococci in early lactation have fewer cases of clinical mastitis and a higher milk production in their first lactation than non infected heifers. J. Dairy Sci. 93:2014-2024. 
Piepers, S., G. Opsomer, E. Meyer, K. Demeyere, H. W. Barkema, A. de Kruif, and S. De Vliegher. 2009. Heifer and quarter characteristics associated with periparturient blood and milk neutrophil apoptosis in healthy heifers and in heifers with subclinical mastitis. J. Dairy Sci. 92:4330-4339.

Sampimon, O. C., S. De Vliegher, H. W. Barkema, J. Sol, and T. J Lam. 2009. Effect of prepartum dry cow antibiotic treatment in dairy heifers on udder health and milk production. J. Dairy Sci. 92:4395-4403.

Schukken, Y. H., D. J. Wilson, F. Welcome, L. Garrison-Tikofsky, and R. N. Gonzalez. 2003. Monitoring udder health and milk quality using somatic cell counts. Vet. Res. 34:579-596.

Smith, K. L., H. R. Conrad, B. A. Amiet, and D. A. Todhunter. 1985. Incidence of environmental mastitis as influenced by dietary vitamin E and selenium. Kieler Milchwiss. Forschung. 37:482-486.

Smith, K. L., J. Hogan, and W. Weiss. 1997. Dietary vitamin E and selenium affect mastitis and milk quality. J. Anim. Sci. 75:1659 1665.

Sordillo, L. M., N. O'Boyle, J. Gandy, C. Corl, and E. Hamilton. 2007. Shifts in thioredoxin reductase activity and oxidant status in mononuclear cells obtained from transition dairy cattle. J. Dairy Sci. 90:1186-1192.

Thompson, K. G., A. J. Fraser, B. M. Harrop, J. A. Kirk, J. Bullians, and D. O. Cordes. 1981. Glutathione peroxidase activity and selenium concentration in bovine blood and liver as indicators of dietary selenium intake. N. Z. Vet. J. 29:3-6.

Weiss, W. P. 1998. Requirements of fat-soluble vitamins for dairy cows: A review. J. Dairy Sci. 81:2493-2501.

Weiss, W. P., J. S. Hogan, K. L. Smith, and K. H. Hoblet. 1990. Relationships among selenium, vitamin E, and mammary gland health in commercial dairy herds. J. Dairy Sci. 73:381-390.

Whelan, N. C., R. A. Bruce, D. H. Samson, A. M. Alexander, and J. B. Tasker. 1992. Evaluation of the production-enhancing effects of Deposel in a dairy herd with marginal selenium deficiency. Proc. Soc. Sheep and Beef Cattle Vet. N.Z. Vet. Assoc. 22:33-42.
Wichtel, J. J. 1998. A review of selenium deficiency in grazing ruminants. Part 1: New roles for selenium in ruminant metabolism. N. Z. Vet. J. 46:47-52.

Wichtel, J. J., A. L. Craigie, H. Varela-Alvarez, and N. B. Williamson. 1994. The effect of intra-ruminal selenium pellets on growth rate, lactation and reproductive efficiency in dairy cattle. N. Z. Vet. J. $42: 205-210$

\section{Appendix}

Table A1. Breakdown by treatment group and days of the quarter samples lost in the fire of the laboratory of microbiology of the Faculty of Sciences of the Universidad Austral de Chile (Valdivia, Chile)

\begin{tabular}{lrcc}
\hline & \multicolumn{3}{c}{ Treatment group } \\
\cline { 2 - 4 } Quarter/days & Unsupplemented & Barium selenate & Se yeast \\
\hline Right front & 26 & & \\
$0-1$ & 106 & 115 & 20 \\
$7-28$ & & & 74 \\
Right rear & 24 & 40 & 20 \\
$0-1$ & 105 & 111 & 73 \\
$7-28$ & & & 20 \\
Left front & 24 & 111 & 79 \\
$0-1$ & 105 & 40 & 20 \\
$7-28$ & & 115 & 75 \\
Left rear & 26 & 612 & 381 \\
$0-1$ & 105 & & \\
$7-28$ & 521 & & \\
Total & & & \\
\hline
\end{tabular}

